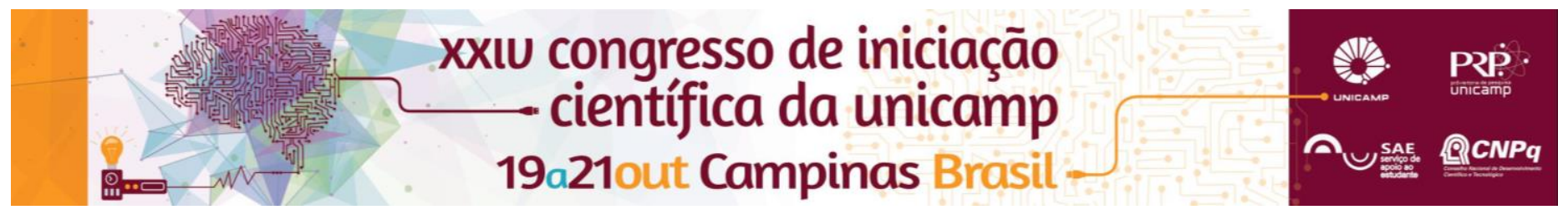

\title{
Indicadores Morfométricos Aplicados a Rede de Drenagem nas Bacias dos Ribeirões Anhumas e Quilombo.
}

\author{
Alexandre L. Rocha (IC), Archimedes Perez F (PQ)
}

\begin{abstract}
Resumo
Análises morfométricas referentes às redes de drenagem das bacias hidrográficas do ribeirão Quilombo e Anhumas, foram associadas aos contextos estruturais, litológicos, pedológicos e geomorfológicos das mesmas, por meio de técnicas relacionadas ao Sistema de Informações Geográficas, SIG, contribuindo para discussão teórica que sistematiza relações entre canais fluviais e os demais elementos da paisagem, ao longo do tempo.
\end{abstract}

\section{Palavras-chave:}

Geomorfologia Fluvial, Morfometria, Bacia Hidrográfica.

\section{Introdução}

Redes de drenagem são fatores ativos no desenvolvimento e esculturação da paisagem terrestre. Em regiões de clima tropical onde há relativa estabilidade tectônica, os canais fluviais se destacam como agentes atuantes em processos de remoção, transporte e deposição de materiais, atuando na elaboração de formas de relevo, assim como, seus comportamentos são reflexos de contextos estruturais, litológicos, pedológicos, climáticos e geomorfológicos. O presente trabalho utiliza técnicas de morfometria aplicadas a rede de drenagem, conceituadas por diversos autores, com o objetivo e relacionar valores quantitativos referentes aos canais fluviais com a ocorrência de padrões de drenagem em característica estruturais, litológicas ou pedológicas específicas. A análise parte da definição de Geossistemas, por Sotchava (1962).

Foram calculadas a Relação Declividade-Extensão (RDE), a partir de Perfil Longitudinal dos ribeirões Anhumas e Quilombo; Fator de assimetria Topográfica Transversal (FSTT) (COX, 1994) e Fator de Assimetria de Bacias de Drenagem (FARB); Densidades Hidrográfica e de Drenagem, por amostra circular de $2 \mathrm{~km}^{2}$, localizadas em canais de primeira ordem (CHRISTOFOLETTI, 1974).

\section{Resultados e Discussão}

A elaboração de Perfis Longitudinais e o consecutivo cálculo de RDE revelaram possíveis níveis de base locais, caracterizados por estruturas e litologias que inviabilizaram 0 aprofundamento do talvegue em determinados setores dos canais fluviais.

Os cálculos de FSTT e FARB revelaram assimetria das duas bacias hidrográficas, ambas descolocadas para o setor direito, representado em 49,58\% de área na Bacia do Anhumas e $32,96 \%$ na bacia do Quilombo.

A Bacia do Quilombo possui litologia mais homogênea, apresentando-se, em sua maior área, sobre o grupo Itararé. No entanto, seu FARB é maior do que encontrado na Bacia do Anhumas, caracterizada basicamente por duas compartimentações geomorfológicas: a primeira à sudeste, relevo altamente dissecado, constituído de granitos e gnaisses datados do pré-cambriano; a segunda caracterizada por relevo levemente ondulado, de litologia basáltica e sedimentar. A margem esquerda da Bacia do Quilombo possui rede de drenagem mais diversificada, de padrão dendrítico, abrigando um extenso canal fluvial, denominado "Ribeirão Jacuba", cuja as densidades hidrográfica e de drenagem dos canais de primeira ordem, variam significativamente conforme a mudança de textura de solo.

Solos mais arenosos possuem drenagens mais ramificadas e de menor comprimento, possuindo maior densidade hidrográfica e menor densidade de drenagem. Já em áreas de solos de textura mais argilosa, observase menor densidade hidrográfica, (quantidade de rios por área) e maior densidade de drenagem em canais de primeira ordem.

Tal fato também é observado no setor direito da Bacia do Quilombo. Á leste e noroeste, aflora a formação Serra Geral, sendo encontrados canais de primeira ordem muito extensos e pouco dissecados.

A relação textura dos solos com densidade de drenagem e hidrográfica também é observada na Bacia do Anhumas, principalmente a nordeste e a noroeste.

A sudeste e a margem direita, encontra-se regiões de maior densidade hidrográfica (de 6 a 9 canais $/ \mathrm{km}^{2}$ ) e menor densidade de drenagem, caracterizadas em relevos dissecados, de estruturas do pré-cambriano, diferenciando significativamente esta região das demais.

\section{Conclusões}

Redes de drenagem e suas características morfométricas estão associadas diretamente com as características estruturais, litológicas, pedológicas, geomorfológicas e climáticas de determinada região. Os processos de evolução hidrográfica ao longo do tempo, são condicionados e condicionantes das características do meio físico ao qual os canais fluviais estão inseridos.

\section{Agradecimentos}

Ao PIBIC/CNPq pelo auxílio financeiro.

Ao Instituto de Geociências da UNICAMP, pelo auxílio em infraestrutura.

Ao Professor Dr. Archimedes Perez Filho, pela orientação.

CHRISTOFOLETTI, A. Geomorfologia. Editora Edgard Blücher LTDA. São Paulo, 1974. pp. 149.

COX, R.T. (1994) Analysis of drainage-basin symmetry as a rapid technique to identify areas of possible

Quaternary tilt.block tectonics: as example from

the Mississipi Embayment. Geological Society of

America Bullelin, 106: 571-581.

SOTCHAVA V.B. Définition de Quelque Nations et Termes de Géographie Physique; Institute de Geographie de la Sibere et Extrem Orient; 3: 94-177, 1962. 